\title{
MRI findings in a child with neuromelioidosis
}

Kaushik Maulik, MD, Gulrej Nisar Shaikh, MBBS, Ananthanarayanan Kasinathan, DM,

Venkatesh Chandrasekaran, MD, Narayanan Parameswaran, MD, and Niranjan Biswal, MD

Neurology ${ }^{\circledR}$ 2020;95:836-837. doi:10.1212/WNL.0000000000010835

Figure MRI brain of index child with neuromelioidosis

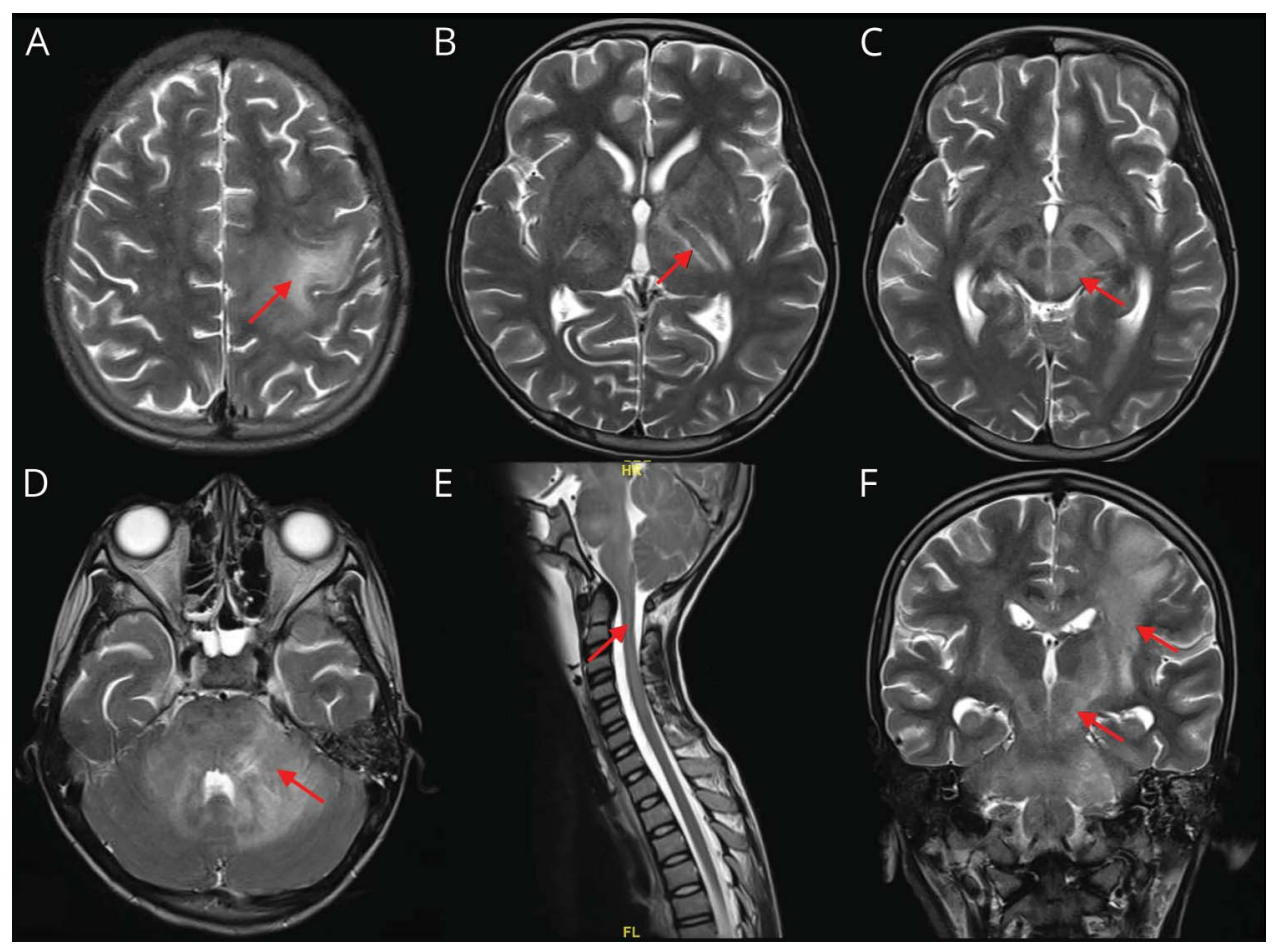

Axial T2-weighted brain MRI reveals hyperintensities in the left postcentral gyrus and centrum semiovale (A), left posterior limb of internal capsule (B), midbrain tegmentum (C), pons, middle cerebellar peduncle, and dentate nucleus of cerebellum (D). (E) Sagittal T2 spine reveals brainstem and cervical spine hyperintensities. (F) Spread along the white matter tracts across longitudinal and commissural fibers is noted in T2 coronal view.

A 10-year-old boy presented with a 2-week history of fever, headache, and altered mentation. Bulbar palsy, 2/5 right hemiparesis, and meningeal signs were evident. CSF was notable for lymphocytosis, high protein, normal glucose, and negative tuberculosis workup. MRI demonstrated hyperintensity along the white matter tracts suggestive of neuromelioidosis (figure) and was confirmed by antibody positivity to indirect hemagglutination for Burkholderia pseudomallei. The child responded to 6 weeks of induction therapy with meropenem and is currently on eradication treatment with doxycycline. Propensity for spread along the white matter tract and brainstem neurotropism is the hallmark of neuromelioidosis, especially the encephalomyelitis type. ${ }^{1}$

\author{
Correspondence \\ Dr. Parameswaran \\ narayanan.p@jipmer.edu.in
}




\section{Study funding}

No targeted funding reported.

\section{Disclosure}

The authors report no disclosures relevant to the manuscript. Go to Neurology.org/N for full disclosures.

\begin{tabular}{|c|c|c|}
\hline Name & Location & Contribution \\
\hline Kaushik Maulik, MD & $\begin{array}{l}\text { Department of } \\
\text { Pediatrics, JIPMER, } \\
\text { Puducherry, India }\end{array}$ & $\begin{array}{l}\text { Patient management, } \\
\text { literature review, initial } \\
\text { draft manuscript } \\
\text { preparation }\end{array}$ \\
\hline $\begin{array}{l}\text { Gulrej Nisar Shaikh, } \\
\text { MBBS }\end{array}$ & $\begin{array}{l}\text { Department of } \\
\text { Pediatrics, JIPMER, } \\
\text { Puducherry, India }\end{array}$ & $\begin{array}{l}\text { Patient management, } \\
\text { literature review, initial } \\
\text { draft manuscript } \\
\text { preparation }\end{array}$ \\
\hline $\begin{array}{l}\text { Ananthanarayanan } \\
\text { Kasinathan, DM }\end{array}$ & $\begin{array}{l}\text { Department of } \\
\text { Pediatrics, JIPMER, } \\
\text { Puducherry, India }\end{array}$ & $\begin{array}{l}\text { Concept and design of the } \\
\text { study, critical review of } \\
\text { manuscript, final approval } \\
\text { of the version to be } \\
\text { published }\end{array}$ \\
\hline
\end{tabular}

Appendix (continued)

\begin{tabular}{lll}
\hline Name & Location & Contribution \\
\hline $\begin{array}{l}\text { Venkatesh } \\
\text { MDandrasekaran, }\end{array}$ & $\begin{array}{l}\text { Department of } \\
\text { Pediatrics, JIPMER, } \\
\text { Puducherry, India }\end{array}$ & $\begin{array}{l}\text { Concept and design of } \\
\text { the study, critical review } \\
\text { of manuscript, final } \\
\text { approval of the } \\
\text { version to be } \\
\text { published }\end{array}$ \\
\hline $\begin{array}{l}\text { Narayanan } \\
\text { Parameswaran, MD }\end{array}$ & $\begin{array}{l}\text { Department of } \\
\text { Pediatrics, JIPMER, } \\
\text { Puducherry, India }\end{array}$ & $\begin{array}{l}\text { Concept and design } \\
\text { of the study, critical } \\
\text { review of manuscript, } \\
\text { final approval of } \\
\text { the version to be } \\
\text { published }\end{array}$ \\
& $\begin{array}{l}\text { Clinician-in-charge, } \\
\text { concept and design of the }\end{array}$ \\
\hline Niranjan Biswal, MD & $\begin{array}{l}\text { Department of } \\
\text { Pediatrics, JIPMER, } \\
\text { Puducherry, India }\end{array}$ & $\begin{array}{l}\text { study, critical review of } \\
\text { manuscript, final approval } \\
\text { of the version to be } \\
\text { published }\end{array}$ \\
& &
\end{tabular}

\section{Reference}

1. Wiersinga WJ, Virk HS, Torres AG, et al. Melioidosis. Nat Rev Dis Primers 2018;4: 17107.

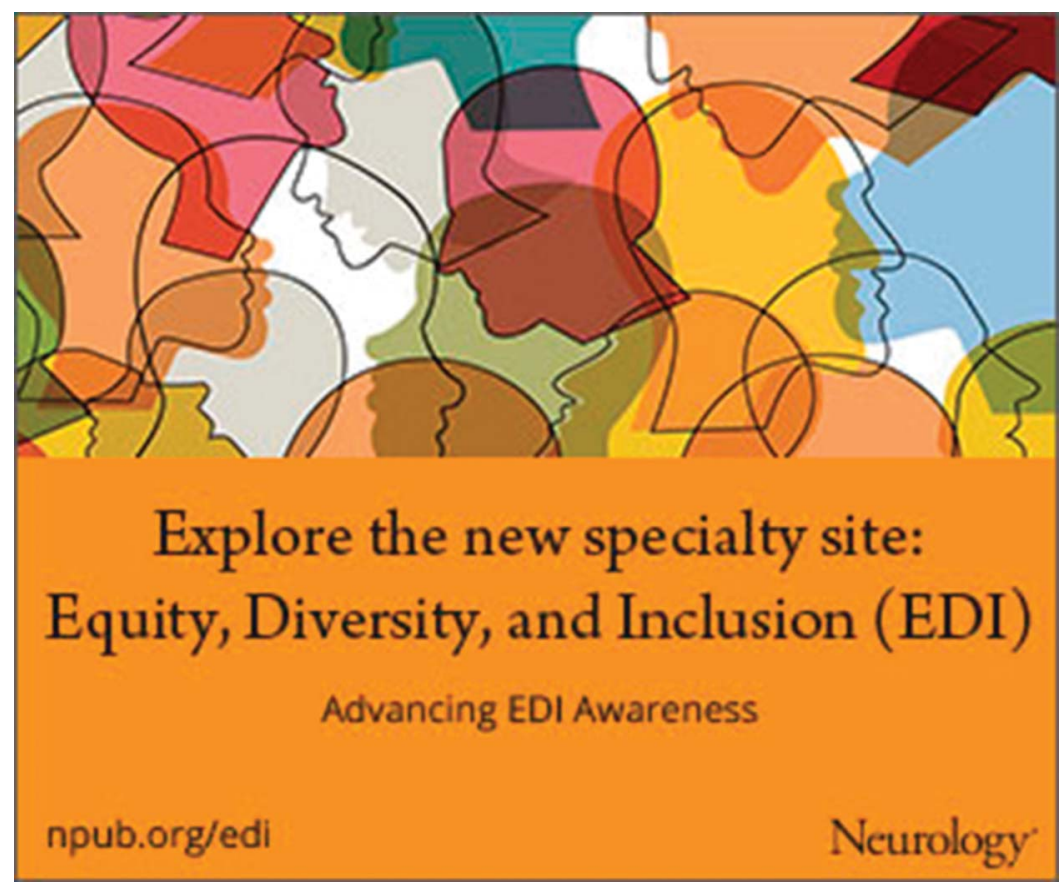




\title{
Neurology
}

\begin{abstract}
MRI findings in a child with neuromelioidosis
Kaushik Maulik, Gulrej Nisar Shaikh, Ananthanarayanan Kasinathan, et al. Neurology 2020;95;836-837 Published Online before print September 15, 2020

DOI 10.1212/WNL.0000000000010835
\end{abstract}

This information is current as of September 15, 2020

$\begin{array}{ll}\begin{array}{l}\text { Updated Information \& } \\ \text { Services }\end{array} & \begin{array}{l}\text { including high resolution figures, can be found at: } \\ \text { http://n.neurology.org/content/95/18/836.full }\end{array} \\ \text { References } & \text { This article cites } 1 \text { articles, } 0 \text { of which you can access for free at: } \\ & \text { http://n.neurology.org/content/95/18/836.full\#ref-list-1 } \\ \text { Subspecialty Collections } & \text { This article, along with others on similar topics, appears in the } \\ & \text { following collection(s): } \\ \text { Bacterial infections } & \text { http://n.neurology.org/cgi/collection/bacterial_infections } \\ & \text { Encephalitis } \\ \text { http://n.neurology.org/cgi/collection/encephalitis } & \text { MRI } \\ & \text { http://n.neurology.org/cgi/collection/mri } \\ & \text { Information about reproducing this article in parts (figures,tables) or in } \\ & \text { its entirety can be found online at: } \\ & \text { http://www.neurology.org/about/about_the_journal\#permissions } \\ & \text { Information about ordering reprints can be found online: } \\ \text { http://n.neurology.org/subscribers/advertise }\end{array}$

Neurology ${ }^{\circledR}$ is the official journal of the American Academy of Neurology. Published continuously since 1951, it is now a weekly with 48 issues per year. Copyright @ 2020 American Academy of Neurology. All rights reserved. Print ISSN: 0028-3878. Online ISSN: 1526-632X.

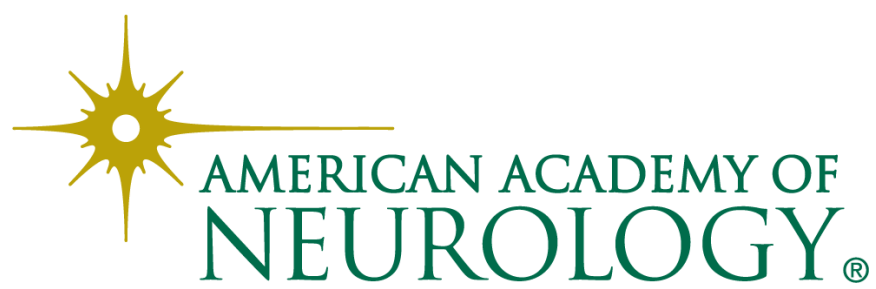

